\title{
Ketamine for the multivariate effect of PTSD: Systematic review and meta-analysis
}

\author{
Rui $\mathrm{Du}^{1}$, Kun $\mathrm{Niu}^{2}$, Guofang $\mathrm{Lu}^{3,4^{*}}$, Yulong Shang ${ }^{4^{*}}$ \\ ${ }^{1}$ Institute for Biomedical Sciences of Pain, Tangdu Hospital, Fourth Military Medical University,
} Xi'an, 710038, China.

${ }^{2}$ Department of Anesthesiology, Key laboratory of Carcinogenesis and Translational Research (Ministry of Education/Beijing), Peking University Cancer Hospital \& Institute, Beijing, 100142, China.

${ }^{3}$ Department of Physiology and Pathophysiology, National Key Discipline of Cell Biology, Fourth Military Medical University, Xi'an, 710032, China.

${ }^{4}$ State Key Laboratory of Cancer Biology and National Clinical Research Center for Digestive Diseases, Xijing Hospital of Digestive Diseases, Fourth Military Medical University, Xi'an, 710032, China.

*To whom correspondence should be addressed:

Guofang Lu, luguofang16@163.com, Yulong Shang, shangyul870222@163.com;

Tel: $+862984771506 \quad$ Fax: +862982539041

Keywords: PTSD, ketamine, meta-analysis 


\section{Summary}

The aim of this systematic review and meta-analysis was to examine the efficacy, anti-effect of ketamine (intervention) for post-traumatic stress disorder (PTSD) patients during analgesia proceeding and mental illness treatment methods, in comparison with control (midazolam, opioid, saline or placebo). The bibliographic databases Cochrane, Embase, Pubmed and Web of Science were searched from inception to 23 May 2021 for randomized controlled trials, case-control and cohort studies included. For continuous and dichotomous outcomes, respectively, we calculated the mean difference using the inverse-variance method and the risk ratio with the Mantel-Haenszel method. In all, ten trials with 705 patients were included. Confirmed by meta-analysis, ketamine didn't increase the prevalence of PTSD by a risk ratio $(95 \% \mathrm{Cl})$ of $0.86(0.61$ to 1.20$), p=0.38$ in 3 trials with 503 patients. Evidence of a difference was found in the PTSD-scales taken between ketamine and control during short durations (months), with a mean difference $(95 \% \mathrm{Cl})$ of $2.45(1.33$ to 3.58$), p<0.001$ in three trials with 65 patients. Another evidence is shown in chronic PTSD (years), with a mean difference $(95 \% \mathrm{Cl}$ ) of $-3.66(-7.05$ to -0.27$), p=0.03$ in three trials with 91 patients. Sub-group analysis underlined the increased benefit of ketamine administration for those in whom the procedure was more than one week in the chronic PTSD group. The adoption of ketamine for the short duration of PTSD is in avoidance, but for chronic PTSD is recommended and, in the opinion of the authors, should be considered as a new therapy in view of its potential to ameliorate arousal, avoidance and dissociative symptoms, neuroticism after trauma needing more animal research and clinical trials. 


\section{Introduction}

According to the fifth updated diagnostic criteria for post-traumatic stress disorder (PTSD), it belongs to "Trauma- and Stressor-Related Dis-order" [1]. Patients with PTSD have pain, repeated recall of the traumatic experience, avoiding traumatic situations, depression, anxiety, substance-use disorders and other symptoms [2]. And PTSD is the most prevalent psychopathological consequence of exposure to traumatic events [3]. The lifetime prevalence of PTSD ranging from 1.3 to $12.2 \%$, and the 1-year prevalence is 0.2 to $3.8 \%$; the varies according to social background and country of residence [4]. PTSD is also associated with suicidal behavior [5], but the relationship is still unclear. PTSD is currently no specific treatment; existing treatments include psychotherapy, medication and innovative interventions, etc. [6-9]. Due to multiplicity and interdependence of biologic features [10-15] and complicated pathogenesis, the pressing need for diagnostic, prognostic, and therapeutic biomarkers about the pathogenesis of PTSD and treatment targets.

Ketamine acts as blocking the excitatory receptor antagonist $\mathrm{N}$-methyl-d-aspartate receptor (NMDA) $[16,17]$ is a versatile agent primarily utilized as a dissociative anesthetic anesthetic [18-21], analgesic [22,23], anti-inflammatory [24,25], and antidepressant [26] drug has reignited research to understand the neurobiological mechanisms underlying these effects of ketamine. However, the molecular mechanisms involved in clinical therapeutic effects the action of ketamine is still unclear. In recent years, data suggest that intravenous ketamine (a single or repeated dose) can quickly reduce the severity of PTSD symptoms in chronic cases (14.6 (25.9), years (SD)) $[27,28]$. But the therapeutic effect of ketamine on PTSD needs further exploration.

In the present study, we conducted a systematic review and meta-analysis to evaluate the relationship between ketamine and PTSD. We did not detect any discernible effect of ketamine on the development of PTSD. Patients with chronic PTSD exhibited significant improvements than acute or short-term PTSD patients after ketamine treatment.

\section{Methods}

This systematic review and network meta-analysis were registered with PROSPERO and follow the preferred reporting project for systematic reviews and meta-analysis (PRISMA) 
recommendations [29].

A detailed systematic review of the following databases was performed: Cochrane Central Register of Controlled Trials; Embase; Pubmed and Web of Science from inception to 23 May 2021. The following search terms were used for Pubmed: ('ketamine' OR 'ketalar' OR 'calipsol' OR 'kalipsol') AND ('PTSD' OR 'posttraumatic stress disorder' OR 'posttraumatic stress symptoms' OR 'acute stress disorder'). Differently, RCT (Randomized Controlled Trial), Case-control study and Cohort study were included. Both dichotomous and continuous variables were separately included. Research articles were also extended to pre-published in BioRivx.

A preliminary screening of the abstract, if found to be suitable, the full text of this article would be further studied. Two authors (Rui and Guofang) independently reviewed all search results based on inclusion and exclusion criteria. The divergent research items were determined by independent researchers (Kun). All included trials were reviewed by authors to ensure that they met the eligibility criteria. The risk of bias was used by Review Manager 5.3. This included: random sequence generation, allocation concealment, blinding of participants and personnel, blinding of outcome assessment, incomplete outcome data, selective reporting and other sources of bias. Disagreements in the process were resolved through discussion until a consensus was reached.

Results related to the terms of 'ketamine' and 'PTSD' were included referred to RCT, Case-control and Cohort studies. We excluded: correspondence, poster abstract, no results of NCT (National ClinicalTrial.gov, paired comparison and unable to obtain the full text.

Two investigators (Rui and Guofang) independently screened the literature based on the above inclusion and exclusion criteria. By revisiting the original text and performing any appropriate calculations or conversions, any discrepancies found would be resolved. Intuitively extracted data includes: the first author, publication time, participants, study interventions, types of outcomes, reasons for exclusion, study control and duration of follow-up.

The primary outcomes were giving ketamine analgesia during treatment on the battlefield to the risk of PTSD in the later stage of the wounded or burn patients. The second outcomes were the rate of the effect of ketamine on the symptom performance of wounded 
patients with confirmed PTSD (classified as early, usually several months), based on multiple psychological assessment scales. The third outcomes were related to the long duration (several years) of PTSD compared to the second outcome. The Mantel-Haenszel (M-H) method was used to pool dichotomous data and to compute the risk ratio (RR) with its corresponding $95 \%$ confidence interval ( $\mathrm{Cl}$ ) was calculated. The inverse variance (IV) method was used to pool continuous data and to calculate standard mean difference with $95 \% \mathrm{Cl}$. Random effects models were used with or without apparent heterogeneity based on $\mathrm{I}^{2}>50 \%$ compared to the fixed effects model $\left(I^{2}<50 \%\right)[30,31]$. Sensitivity analysis was performed to assess the stability of the meta-analysis. $\mathrm{P}<0.05$ was considered statistically significant.

The software used was Review Manager (RevMan, version5.3.5. Copenhagen: The Nordic Cochrane Centre, The Cochrane Collaboration, 2014).

\section{Results}

The process of retrieving and screening the research was shown in a flowchart in Fig. 1. linitial searching found 3252 articles, including 328 duplicates, leaving 2924 to be screened according to the previously formulated retrieval strategies. After exclusion by title or abstract of 2901 articles, 23 full text articles were reviewed and assessed for eligibility. Of these, 13 were further excluded because 2 were correspondence without chart data [32,33], 2 were poster abstract without chart data [34,35], 2 were NCT finished without results posted [NCT02398136, NCT02655692], 3 were abstracts unavailable to obtain full texts [36-38] and 4 were paired comparison unconsidered to include in Meta-analysis (Fig.1) [39-42]. Finally, 10 studies that met (5 RCT studies, 3 Case-control studies and 2 Cohort studies) our predetermined inclusion criteria and were incorporated in this study. Details of the screening process were shown in Fig. 1 and the results of the risk of bias assessment were found in Fig. 2. All 10 studies reported the effect of ketamine analgesia on the early occurrence of PTSD after battlefield rescue or burned patients [43-45], symptom changes in short duration (months) of PTSD patients with a dose of ketamine $(0.5 \mathrm{mg} / \mathrm{kg})[27,28,46]$ and the same for long duration (years) of PTSD patients [47-50].

The 10 studies involved a total of 705 patients, and were allocated to eligible study groups (Fig. 1). Characteristics of the trials were presented in Table 1. Of these, a total of 442 
medRxiv preprint doi: https://doi.org/10.1101/2021.06.13.21258836; this version posted June 15, 2021. The copyright holder for this preprint (which was not certified by peer review) is the author/funder, who has granted medRxiv a license to display the preprint in perpetuity.

All rights reserved. No reuse allowed without permission.

patients were assigned to ketamine or (S)-ketamine and 263 were assigned to control (i.e. ketorolac, midazolam, normal saline, opioid or placebo, Table 1). Patients in 5 studies (Table 1) $[43-46,48]$ received diagnosis of PTSD assessed with a score of PTSD Checklist (PCL) [51]. Patients in 4 studies (Table 1) $[27,28,46,48]$ received the Clinician-Administered PTSD Scale (CAPS) [52]. Patients in 4 studies (Table 1) $[27,28,47,49]$ received Impact of Event Scale-Revised (IES-R) [53]. Patients in two studies (Table 1) [49,50] received Acute Stress Disorder Scale (ASDS) [54].

Three studies [43-45] including 503 patients (ketamine 349, control 154) in battlefield reported no significant reduction of PTSD prevalence (Fig. 3) with ketamine (no dose list) by a risk ratio $(95 \% \mathrm{Cl})$ of $0.86(0.61-1.20), p=0.38,12=52 \%$ compared with control.

Three studies $[47,48,50]$ including 67 patients (ketamine 29, control 38) reported scores changed in short duration of PTSD (months) by scales of ASDS (four subscales, including dissociation, reexperiencing, avoidance and hyperarousal) [50], IES-R, PCL and CAPS (Fig. 4). Compared with control, ketamine $(0.5 \mathrm{mg} / \mathrm{kg})$ aggravated PTSD symptoms (Fig. 4) by a mean difference $(95 \% \mathrm{Cl})$ of $2.45(1.33-3.58), p<0.001,12=0 \%$. Varying numbers of patients were analyzed for each time-point ( 1 day: ketamine 16 , control 14; < 3 days: ketamine 13 , control 24; 1 week: ketamine 11, control 10). Subgroup analysis showed no influence of ketamine post-infusion during different times on this outcome $(p=0.16)$. Including one study without infusion time [49], ketamine aggravated PTSD symptoms (Fig. S1) by a mean difference (95\% Cl) of $1.72(0.95-2.48), p<0.001,12=0 \%$.

Our third co-primary outcome, including 91 patients (ketamine 47, control 44) $[27,28,46]$ reported scores changed in long duration of PTSD (years) by scales of CAPS, IES-R and PCL (Fig. 5). Compared with control, ketamine $(0.5 \mathrm{mg} / \mathrm{kg}$ ) relieved PTSD symptoms (Fig. 5) by a mean difference $(95 \% \mathrm{Cl})$ of $-3.66(-7.05-0.27), p=0.03,12=35 \%$. Varying numbers of patients were analyzed for each time-point ( 1 day: ketamine 25 , control 25 ; 1 week: ketamine 22, control 19; 2 weeks: ketamine 15, control 15). Subgroup analysis showed the long-term influence of decreasing assessment scores (relief effect) after infusion ( $p=0.007$ ). Mean difference $(95 \% \mathrm{Cl}$ ) for 1 day, 1 week and 2 weeks were respectively, -0.19 (-3.34-2.96), -11.02 (-19.61--2.43) and -8.55 (-14.41--2.69). 
medRxiv preprint doi: https://doi.org/10.1101/2021.06.13.21258836; this version posted June 15, 2021. The copyright holder for this preprint (which was not certified by peer review) is the author/funder, who has granted medRxiv a license to display the preprint in perpetuity.

All rights reserved. No reuse allowed without permission.

\section{Discussion}

In the present study, we identified that there was no effect on the development of PTSD for injured soldiers (e.g. firearm, explosive, burn or accident) on battlefield who was receiving ketamine or not. The symptoms were aggravated for the patients who had been diagnosed of PTSD with a short duration of disease (months) after the administration of ketamine. However, the symptoms were ameliorated for the patients with a chronic PTSD (years) sfter ketamine treatment. The results indicate that ketamine treatment was not related to the development of PTSD but was associated with the disease duration in PTSD patients.

It is traditionally believed that ketamine administration is associated with an increased incidence of PTSD. However, in our study, for injury soldiers, there is no significant difference between the development of PTSD and the treatment of ketamine. Although it is not clear why there is a difference in results, our findings are also supported by Mion et al [45] in that ketamine did not increase the high risk of PTSD. Administration of ketamine during a stressful event may increase the prevalence, reduce the preventive effect, or have no effect on the subsequent development of PTSD [43,45].

To our surprise, we found that ketamine can significantly alleviate the symptoms of PTSD with a long-term course, and without obvious symptoms of psychosis or mania. This has application significance for the clinical therapeutic effect of ketamine. Previous reports by Kyle et al. who used ketamine on Major Depressive Disorder (MDD), and found that rapid antidepressant effects of intranasal ketamine on MDD [26,55]. Interestingly, there has a similar therapeutic effect on PTSD after ibuprofen, a NSAIDs [56]. Possible mechanisms underlying ketamine's therapeutic effects could be related to ketamine could rapidly increase synaptic connections in the prefrontal cortex and reverse the behavioral and neuronal changes caused by chronic stress in rats, partly by activating mammalian-targeted rapamycin signaling pathways and stimulation of brain-derived neurotrophic factor signals $[27,57,58]$. In addition, repeated injections of ketamine are safe for patients with chronic PTSD and are generally well tolerated, with only short-term mental and hemodynamic side effects [28].

On the contrary, through comprehensive data analysis, we also found that ketamine can aggravate the symptoms for diagnoses of PTSD with a short-term course, including within a 
week. It is known that the half-life of ketamine under anesthesia is 2-3 hours, the psycho-simulating symptoms last up to 3 days [49], and the effect can be observed up to 1 week under a single dose (Fig. 4). One possibility is that ketamine overstimulates the stress-induced glutamate-glucocorticoid interaction in the early stage of trauma, which in turn leads to stronger dissociation symptoms and fragmentation to consolidate traumatic memories and aggravate the symptoms [49]. In addition, ketamine could rapidly induce synapses in the brain-derived neurotrophic factor (BDNF) pathway and increase pro-inflammatory cytokines, and then activates microglia to aggravate the symptoms of PTSD [59].

In summary, results from the current study demonstrated that in the analgesia proceeding, the development of PTSD will not be affected by receiving ketamine or not. For chronic course, but not acute or short-term course of disease, facilitated damage caused by PTSD after ketamine treatment.

\section{Limitation}

We cannot exclude the possibility that the difference of ketamine's effect is caused by different statistical methods and standards. In addition, the results confirm that treatment of ketamine could ameliorate the symptoms caused by PTSD. However, we need to further verify this at both the animal research level and clinical studies. And the definitely mechanism of the positive or negative effect of ketamine is still unclear.

\section{Acknowledgements}

This work was supported by grants from National Natural Science Foundation of China (81773072).

\section{Author Contributions}

Rui Du designed the study, searched articles and analyzed data. Kun Niu analysed data. Guofang Lu searched articles and wrote the manuscript. Yulong Shang provided academic advice to the study and revised the manuscript. 
medRxiv preprint doi: https://doi.org/10.1101/2021.06.13.21258836; this version posted June 15, 2021. The copyright holder for this preprint (which was not certified by peer review) is the author/funder, who has granted medRxiv a license to display the preprint in perpetuity.

All rights reserved. No reuse allowed without permission.

\section{Competing Interests}

The authors have declared that no competing interest exists.

\section{References}

1. American Psychiatric Association. Di-agnostic and statistical manual of mental disorders, 5th ed.: DSM-5. Arlington, VA:American Psychiatric Publishing, 2013.

2. Pietrzak RH, Goldstein RB, Southwick SM, et al. Prevalence and Axis I comorbidity of full and partial posttraumatic stress disorder in the United States: results from Wave 2 of the National Epidemiologic Survey on Alcohol and Related Conditions. J Anxiety Disord 2011; 25: 456-65.

3. Shalev A, Liberzon I, Marmar C. Post-Traumatic Stress Disorder. N Engl J Med 2017; 376: 2459-69.

4. Karam EG, Friedman MJ, Hill ED, et al. Cumulative traumas and risk thresholds: 12-month PTSD in the World Mental Health (WMH) surveys. Depress Anxiety 2014; 31: 130-42.

5. Sareen J, Cox BJ, Stein MB, et al. Physical and mental comorbidity, disability, and suicidal behavior associated with posttraumatic stress disorder in a large community sample. Psychosom Med 2007; 69: 242-8.

6. Roberts NP, Roberts PA, Jones N, et al. Psychological interventions for post-traumatic stress disorder and comorbid substance use disorder: A systematic review and meta-analysis. Clin Psychol Rev 2015; 38: 25-38.

7. Steenkamp MM, Litz BT, Hoge CW, et al. Psychotherapy for Military-Related PTSD: A Review of Randomized Clinical Trials. JAMA 2015; 314: 489-500.

8. Mohamed S, Rosenheck RA. Pharmacotherapy of PTSD in the U.S. Department of Veterans Affairs: diagnostic- and symptom-guided drug selection. I Clin Psychiatry 2008; 69: 959-65.

9. Metcalf $O$, Varker T, Forbes D, et al. Efficacy of Fifteen Emerging Interventions for the Treatment of Posttraumatic Stress Disorder: A Systematic Review. J Trauma Stress 2016; 29: 88-92.

10. Mehta $\mathrm{D}$, Klengel $\mathrm{T}$, Conneely KN, et al. Childhood maltreatment is associated with distinct genomic and epigenetic profiles in posttraumatic stress disorder. Proc Natl Acad Sci U S A 2013; 110: 8302-7.

11. Smoller JW. The Genetics of Stress-Related Disorders: PTSD, Depression, and Anxiety Disorders. Neuropsychopharmacology 2016; 41: 297-319.

12. Yehuda R. Post-traumatic stress disorder. N Engl J Med 2002; 346: 108-14.

13. Eraly SA, Nievergelt CM, Maih ofer AX, et al. Assessment of plasma C-reactive protein as a biomarker of posttraumatic stress disorder risk. JAMA Psychiatry 2014; 71: 423-31.

14. Minassian A, Maihofer AX, Baker DG, et al. Association of Predeployment Heart Rate Variability With Risk of Postdeployment Posttraumatic Stress Disorder in Active-Duty Marines. JAMA Psychiatry 2015; 72: 979-86.

15. Germain A. Sleep disturbances as the hallmark of PTSD: where are we now? Am J 
medRxiv preprint doi: https://doi.org/10.1101/2021.06.13.21258836; this version posted June 15, 2021. The copyright holder for this preprint (which was not certified by peer review) is the author/funder, who has granted medRxiv a license to display the preprint in perpetuity.

All rights reserved. No reuse allowed without permission.

Psychiatry 2013; 170: 372-82.

16. Hu YD, Xiang YT, Fang JX, et al. Single i.v. ketamine augmentation of newly initiated escitalopram for major depression: results from a randomized, placebo-controlled 4-week study. Psychol Med 2016; 46: 623-35.

17. Yang F, Liu Y, Yu Q, et al. Analysis of 17948 pediatric patients undergoing procedural sedation with a combination of intranasal dexmedetomidine and ketamine. Paediatr Anaesth 2019; 29: 85-91.

18. Gomez de Segura IA, De Rossi R, Santos M, et al. Epidural injection of ketamine for perineal analgesia in the horse. Vet Surg 1998; 27: 384-91.

19. Green $\mathrm{CJ}$, Knight J, Precious $\mathrm{S}$, et al. Ketamine alone and combined with diazepam or xylazine in laboratory animals: a 10 year experience. Lab Anim 1981; 15: 163-70.

20. Hawksworth C, Serpell M. Intrathecal anesthesia with ketamine. Reg Anesth Pain Med 1998; 23: 283-8.

21. Kathirvel S, Sadhasivam S, Saxena A, et al. Effects of intrathecal ketamine added to bupivacaine for spinal anaesthesia. Anaesthesia 2000; 55: 899-904.

22. Carr DB, Goudas LC, Denman WT, et al. Safety and efficacy of intranasal ketamine for the treatment of breakthrough pain in patients with chronic pain: a randomized, double-blind, placebo-controlled, crossover study. Pain 2004; 108: 17-27.

23. Marchetti F, Coutaux A, Bellanger A, et al. Efficacy and safety of oral ketamine for the relief of intractable chronic pain: A retrospective 5-year study of 51 patients. Eur $J$ Pain 2015; 19: 984-93.

24. Hirsiger $\mathrm{S}$, Simmen HP, Werner $\mathrm{CM}$, et al. Danger signals activating the immune response after trauma. Mediators Inflamm 2012; 2012: 315941.

25. Selye $H$. Forty years of stress research: principal remaining problems and misconceptions. Can Med Assoc J 1976; 115: 53-6.

26. Lapidus KA, Levitch CF, Perez AM, et al. A randomized controlled trial of intranasal ketamine in major depressive disorder. Biol Psychiatry 2014; 76: 970-6.

27. Feder A, Parides MK, Murrough JW, et al. Efficacy of intravenous ketamine for treatment of chronic posttraumatic stress disorder: a randomized clinical trial. JAMA Psychiatry 2014; 71: 681-8.

28. Feder A, Costi S, Rutter SB, et al. A Randomized Controlled Trial of Repeated Ketamine Administration for Chronic Posttraumatic Stress Disorder. Am I Psychiatry 2021; 178: 193-202.

29. Moher D, Liberati A, Tetzlaff J, et al. Preferred reporting items for systematic reviews and meta-analyses: the PRISMA statement. J Clin Epidemiol 2009; 62: 1006-12.

30. Higgins JP, Thompson SG. Quantifying heterogeneity in a meta-analysis. Stat Med 2002; 21: 1539-58.

31. Choi SW, Lam DM. Heterogeneity in meta-analyses. Comparing apples and oranges? Anaesthesia 2017; 72: 532-4.

32. D'Andrea D, Andrew Sewell R. Transient resolution of treatment-resistant posttraumatic stress disorder following ketamine infusion. Biol Psychiatry 2013; 74: e13-4.

33. Zeng MC, Niciu MJ, Luckenbaugh DA, et al. Acute stress symptoms do not worsen in posttraumatic stress disorder and abuse with a single subanesthetic dose of 
medRxiv preprint doi: https://doi.org/10.1101/2021.06.13.21258836; this version posted June 15, 2021. The copyright holder for this preprint (which was not certified by peer review) is the author/funder, who has granted medRxiv a license to display the preprint in perpetuity.

All rights reserved. No reuse allowed without permission.

ketamine. Biol Psychiatry 2013; 73: e37-8.

34. Duek O, Levy I, Yutong L, et al. PTSD Augmented Psychotherapy With Ketamine (KPE) - First Results. Biological psychiatry 2019; 10: S122.

35. Shiroma P, McManus E, Voller E. Repeated Sub-Anesthetic Ketamine to Enhance Prolonged Exposure Therapy in Post-Traumatic Stress Disorder: a Proof-Of-Concept Study. Biological psychiatry 2020; 87: S217.

36. Halstead M, Reed S, Krause R, et al. Ketamine-Assisted Psychotherapy for PTSD Related to Racial Discrimination. Clinical Case Studies 2021; 6: und efined.

37. Kato H, Koizumi T, Takeuchi $\mathrm{H}$, et al. Analgesia for Days With Low Dose Ketamine vs Ketorolac in Chronic Pain and PTSD Patients. Neuropsychopharmacology 2020; 45: 110-1.

38. Krystal J, Sanacora G, Abdallh C, et al. Ketamine and the pursuit of rapid-acting antidepressants for the treatment of depression and PTSD symptoms. International Journal of Neuropsychopharmacology 2016; 19: undefined.

39. Albott CS, Lim KO, Forbes MK, et al. Efficacy, Safety, and Durability of Repeated Ketamine Infusions for Comorbid Posttraumatic Stress Disorder and Treatment-Resistant Depression. J Clin Psychiatry 2018; 79.

40. Dai D, Lacadie CM, Holmes SE, et al. Ketamine Normalizes the Structural Alterations of Inferior Frontal Gyrus in Depression. Chronic Stress (Thousand Oaks) 2020; 4: 2470547020980681.

41. Keizer BM, Roache JD, Jones JR, et al. Continuous Ketamine Infusion for Pain as an Opportunity for Psychotherapy for PTSD: A Case Series of Ketamine-Enhanced Psychotherapy for PTSD and Pain (KEP-P2). Psychother Psychosom 2020; 89: 326-9.

42. Ross C, Jain R, Bonnett CJ, et al. High-dose ketamine infusion for the treatment of posttraumatic stress disorder in combat veterans. Ann Clin Psychiatry 2019; 31: 271-9.

43. McGhee LL, Maani CV, Garza TH, et al. The correlation between ketamine and posttraumatic stress disorder in burned service members. J Trauma 2008; 64: S195-8; Discussion 57-8.

44. McGhee LL, Maani CV, Garza TH, et al. The intraoperative administration of ketamine to burned U.S. service members does not increase the incidence of post-traumatic stress disorder. Mil Med 2014; 179: 41-6.

45. Mion G, Le Masson J, Granier C, et al. A retrospective study of ketamine administration and the development of acute or post-traumatic stress disorder in 274 war-wounded soldiers. Anaesthesia 2017; 72: 1476-83.

46. Pradhan B, Mitrev L, Moaddell R, et al. $d$-Serine is a potential biomarker for clinical response in treatment of post-traumatic stress disorder using $(\mathrm{R}, \mathrm{S})$-ketamine infusion and TIMBER psychotherapy: A pilot study. Biochim Biophys Acta Proteins Proteom 2018; 1866: 831-9.

47. Dadabayev AR, Joshi SA, Reda MH, et al. Low Dose Ketamine Infusion for Comorbid Posttraumatic Stress Disorder and Chronic Pain: A Randomized Double-Blind Clinical Trial. Chronic Stress (Thousand Oaks) 2020; 4: 2470547020981670.

48. Pradhan BK, Wainer IW, Moaddell R, et al. Trauma Interventions using Mindfulness Based Extinction and Reconsolidation (TIMBER) psychotherapy prolong the 
therapeutic effects of single ketamine infusion on posttraumatic stress disorder and comorbid depression: a pilot randomized, placebo-controlled, crossover clinical trial. Asia Pac Clin Transl Nerv Syst Dis 2017; 2: 80-90.

49. Schonenberg $M$, Reichwald $U$, Domes $G$, et al. Effects of peritraumatic ketamine medication on early and sustained posttraumatic stress symptoms in moderately injured accident victims. Psychopharmacology (Berl) 2005; 182: 420-5.

50. Schonenberg $M$, Reichwald $U$, Domes $G$, et al. Ketamine aggravates symptoms of acute stress disorder in a naturalistic sample of accident victims. J Psychopharmacol 2008; 22 : 493-7.

51. Weathers F, Litz B, Herman D, et al. The PTSD checklistcivilian version (PCL-C). National Center for PTSD - Behavioral Sciences Division, Boston, MA, 1994.

52. Weathers FW, Keane TM, Davidson JR. Clinician-administered PTSD scale: a review of the first ten years of research. Depress Anxiety 2001; 13: 132-56.

53. Weiss DS, Marmar CR. The Impact of Event Scale-Revised. In: Wilson J, Keane TM, eds. Assessing Psychological Trauma and PTSD. New York, NY: Guilford, 1996: 399-411.

54. Bryant RA, Moulds ML, Guthrie RM. Acute Stress Disorder Scale: a self-report measure of acute stress disorder. Psychol Assess 2000; 12: 61-8.

55. Parise EM, Alcantara LF, Warren BL, et al. Repeated ketamine exposure induces an enduring resilient phenotype in adolescent and adult rats. Biol Psychiatry 2013; 74: 750-9.

56. Lee B, Sur B, Yeom M, et al. Effects of systemic administration of ibuprofen on stress response in a rat model of post-traumatic stress disorder. Korean J Physiol Pharmacol 2016; 20: 357-66.

57. Li N, Lee $B$, Liu RJ, et al. mTOR-dependent synapse formation underlies the rapid antidepressant effects of NMDA antagonists. Science 2010; 329: 959-64.

58. Li N, Liu RJ, Dwyer JM, et al. Glutamate N-methyl-D-aspartate receptor antagonists rapidly reverse behavioral and synaptic deficits caused by chronic stress exposure. Biol Psychiatry 2011; 69: 754-61.

59. Kim YK, Na KS. Role of glutamate receptors and glial cells in the pathophysiology of treatment-resistant depression. Prog Neuropsychopharmacol Biol Psychiatry 2016; 70: 117-26. 
medRxiv preprint doi: https://doi.org/10.1101/2021.06.13.21258836; this version posted June 15, 2021. The copyright holder for this preprint (which was not certified by peer review) is the author/funder, who has granted medRxiv a license to display the preprint in perpetuity.

All rights reserved. No reuse allowed without permission. 
Table 1 Included study characteristics, intervention, duration, scales and study method.

\begin{tabular}{|c|c|c|c|c|c|}
\hline Sources & Subjects & Intervention (n, dose) & Duration of PTSD & Scales & Study method \\
\hline Dadabayev et al., 2020 & $\mathrm{CP}+\mathrm{PTSD}$ & $\begin{array}{l}\text { Ketamine }(11,0.5 \mathrm{mg} / \mathrm{kg}) \\
\text { Ketorolac }(10,15 \mathrm{mg})\end{array}$ & $\geq 3$ months (both) & IES-R & $\mathrm{RCT}$ \\
\hline Feder et al., 2014 & PTSD & $\begin{array}{l}\text { Ketamine }(22,0.5 \mathrm{mg} / \mathrm{kg}) \\
\text { Midazolam }(19,0.045 \mathrm{mg} / \mathrm{kg})\end{array}$ & $\begin{array}{l}\text { Mean } \pm \text { SD (year) } \\
\text { Ketamine: } 14.2 \pm 12.3 \\
\text { Midazolam: } 11.9 \pm 14.0\end{array}$ & $\begin{array}{l}\text { CAPS-5 } \\
\text { IES-R }\end{array}$ & $\mathrm{RCT}$ \\
\hline Feder et al., 2021 & PTSD & $\begin{array}{l}\text { Ketamine }(15,0.5 \mathrm{mg} / \mathrm{kg}) \\
\text { Midazolam }(15,0.045 \mathrm{mg} / \mathrm{kg})\end{array}$ & $\begin{array}{l}\text { Mean } \pm \text { SD (year) } \\
\text { Ketamine: } 15.1 \pm 17.8 \\
\text { Midazolam: } 14.6 \pm 7.8\end{array}$ & $\begin{array}{l}\text { CAPS-5 } \\
\text { IES-R }\end{array}$ & $\mathrm{RCT}$ \\
\hline McGhee et al., 2007 & PTSD/non- & $\begin{array}{l}\text { Ketamine }(119, \text { not list }) \\
\text { No ketamine }(28, \text { not list })\end{array}$ & Not list & $\begin{array}{l}\text { PCL-M } \\
\text { (Military) }\end{array}$ & Case-control \\
\hline McGhee et al., 2014 & PTSD/non- & $\begin{array}{l}\text { Ketamine }(189, \text { not list }) \\
\text { No ketamine }(28, \text { not list })\end{array}$ & Not list & $\begin{array}{l}\text { PCL-M } \\
\text { (Military) }\end{array}$ & Case-control \\
\hline Mion et al., 2017 & PTSD/non- & $\begin{array}{l}\text { Ketamine (41, not list) } \\
\text { Midazolam (26, not list) }\end{array}$ & Not list & $\mathrm{PCL}$ & Case-control \\
\hline Pradhan et al., 2017 & PTSD & $\begin{array}{l}\text { Ketamine }(5,0.5 \mathrm{mg} / \mathrm{kg}) \\
\text { Normal saline }(4, \text { not list })\end{array}$ & $\geq 6$ months (both) & $\begin{array}{l}\text { CAPS } \\
\text { PCL }\end{array}$ & $\mathrm{RCT}$ \\
\hline Pradhan et al., 2018 & PTSD & $\begin{array}{l}\text { Ketamine }(10,0.5 \mathrm{mg} / \mathrm{kg}) \\
\text { Normal saline }(10, \text { not list })\end{array}$ & $\begin{array}{l}\text { Mean } \pm \text { SD (year) } \\
\text { Ketamine: } 15.0 \pm 9.0 \\
\text { Normal saline: } 15.4 \pm 11.7\end{array}$ & $\begin{array}{l}\text { CAPS } \\
\text { PCL }\end{array}$ & $\mathrm{RCT}$ \\
\hline Schönenberg et al., 2005 & PTSD & $\begin{array}{l}\text { Opioids ( } 27 \text {, not list) } \\
\text { Racemic ketamine (17, not list) } \\
\text { (S)-ketamine }(12, \text { not list })\end{array}$ & $\begin{array}{l}\text { Mean } \pm \text { SD (month) } \\
\text { Opioids: } 14.0 \pm 5.3 \\
\text { Racemic ketamine: } 12.8 \pm 5.8 \\
\text { (S)-ketamine: } 10.7 \pm 3.4\end{array}$ & $\begin{array}{l}\text { PDEQ } \\
\text { ASDS } \\
\text { IES }\end{array}$ & Cohort \\
\hline Schönenberg et al., 2008 & PTSD & $\begin{array}{l}\text { Non-Opioids (13, not list) } \\
\text { Opioids (24, not list) } \\
\text { Ketamine (13) }\end{array}$ & Early post-traumatic (not list) & $\begin{array}{l}\text { PDEQ } \\
\text { ASDS }\end{array}$ & Cohort \\
\hline
\end{tabular}




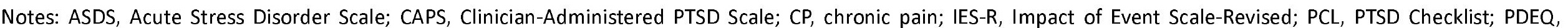
Peritraumatic Dissociative Experiences Questionnaire; RCT, Randomized Controlled Trial. 


\section{Figure legends}

Figure 1 PRISMA flowchart of included and excluded studies.

Figure 2 Summary table illustrating risk of bias results for included studies. Green circle, low risk; yellow circle, some concerns; red circle, high risk.

Figure 3 Forest plot of the prevalence of PTSD in battlefield analgesia by ketamine. $\mathrm{M}-\mathrm{H}$, Mantel-Haenszel.

Figure 4 PTSD-scale scores of short duration (months) by ketamine administration (ketamine vs. control). IV, inverse variance; SD, standard deviation.

Figure 5 PTSD-scale scores of long duration (chronic, years) patients by ketamine.

administration (ketamine vs. control). IV, inverse variance; SD, standard deviation.

Figure S1 PTSD-scale scores of short duration (months) by ketamine administration.

(ketamine vs. control, full scales). IV, inverse variance; SD, standard deviation. 


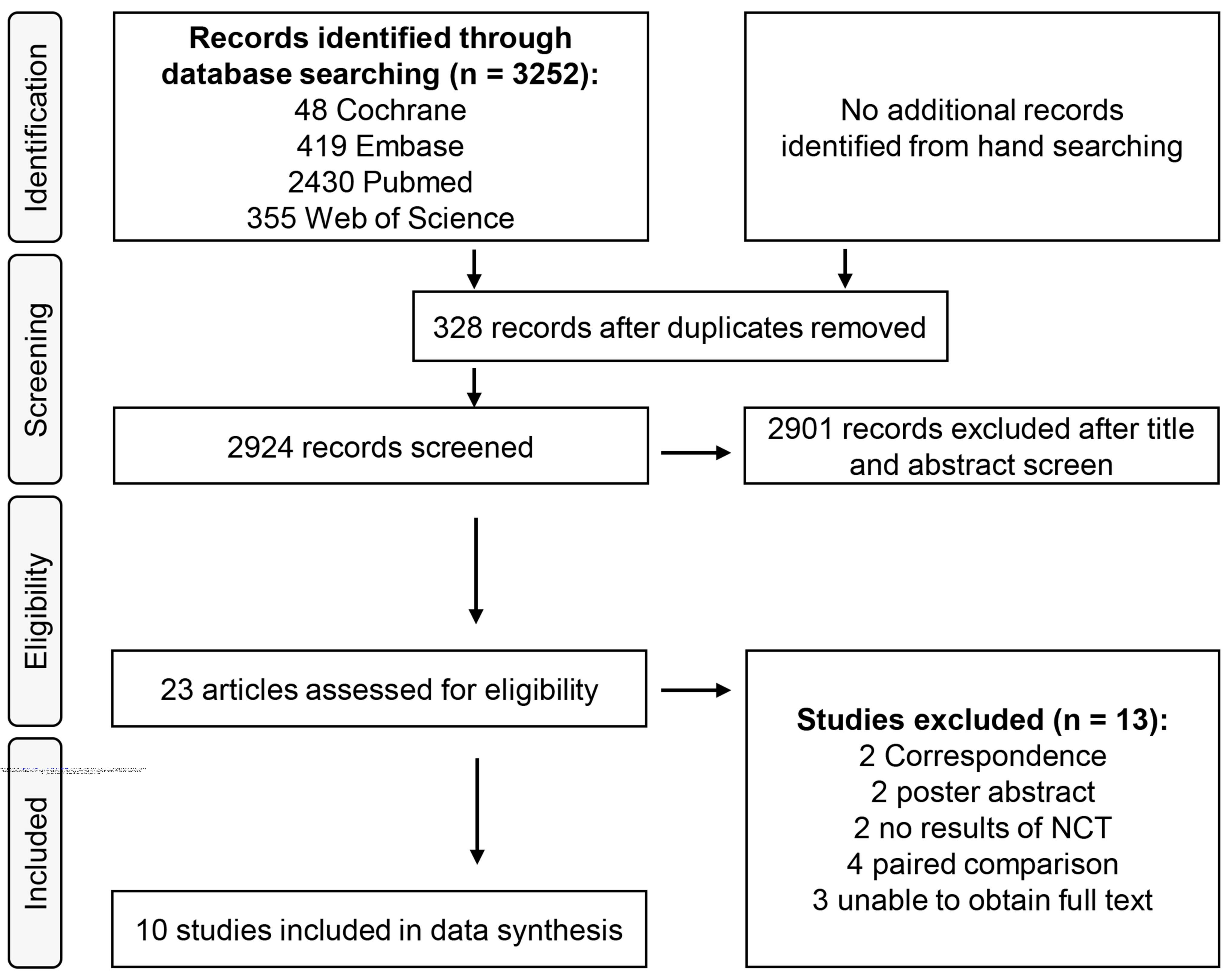




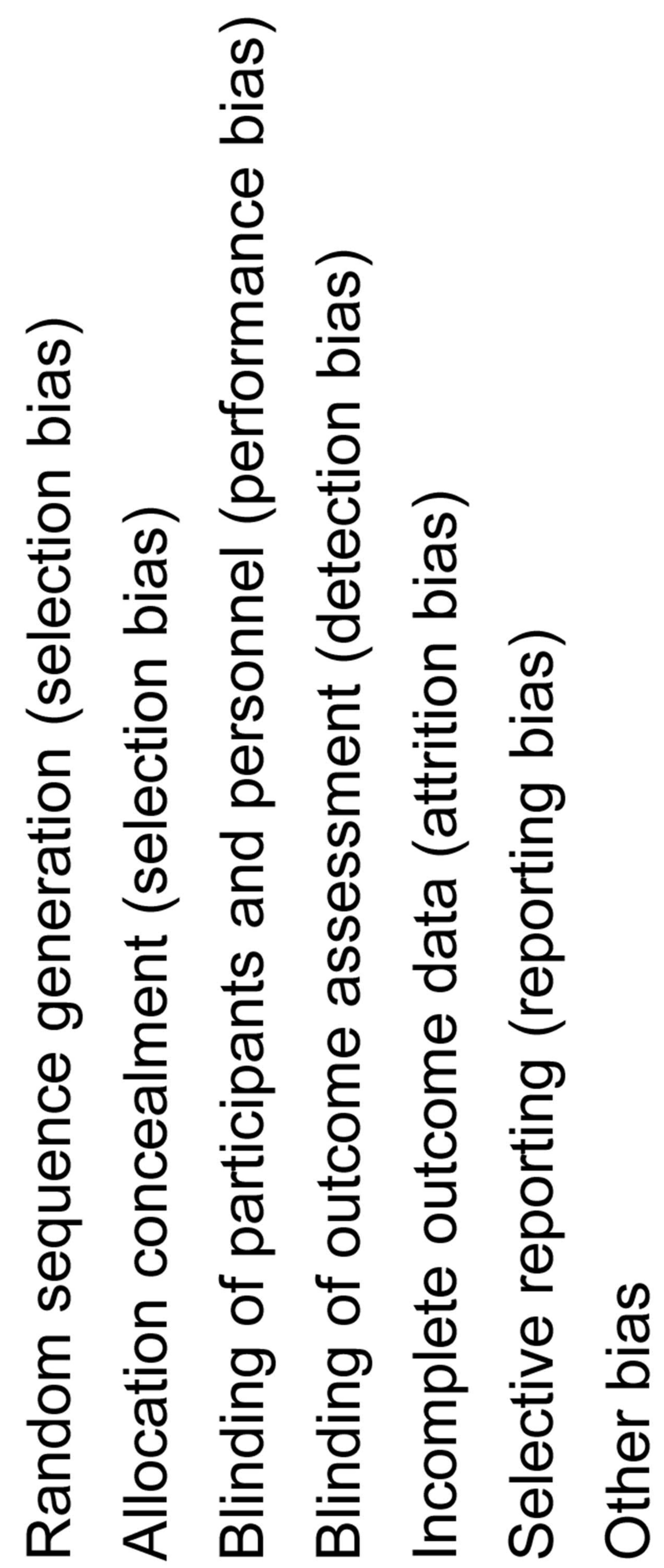

Dadabayev 2020

Feder 2014

Feder 2021

McGhee 2007

McGhee 2014

Mion 2017

\begin{tabular}{|c|c|c|c|c|c|c|}
\hline & ? & + & + & 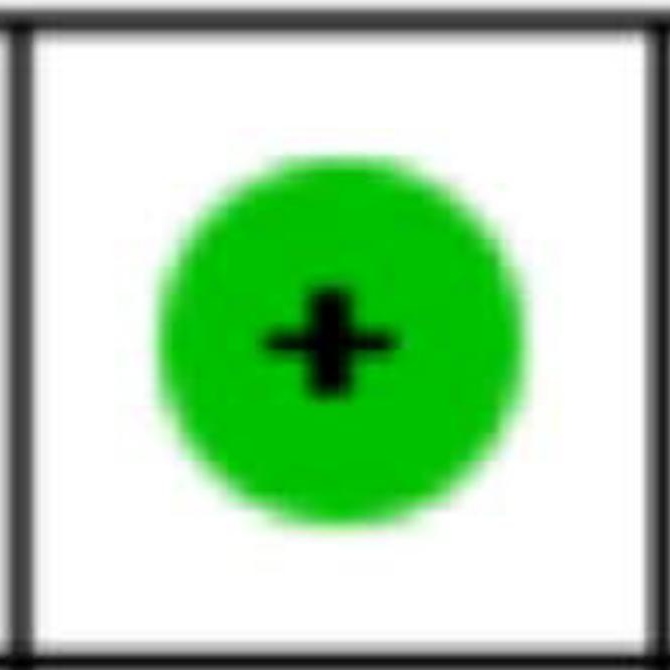 & + & \\
\hline & & 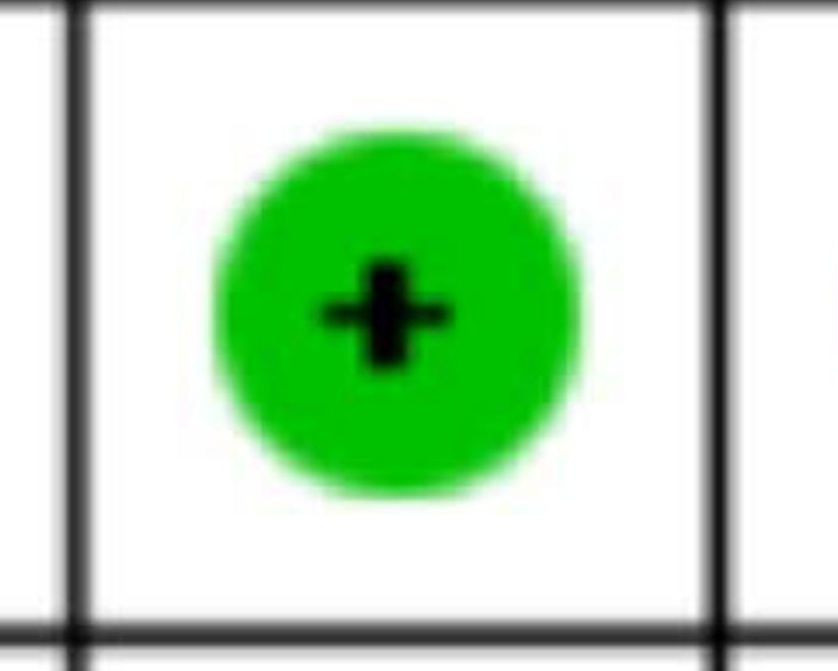 & † & + & & \\
\hline & & & 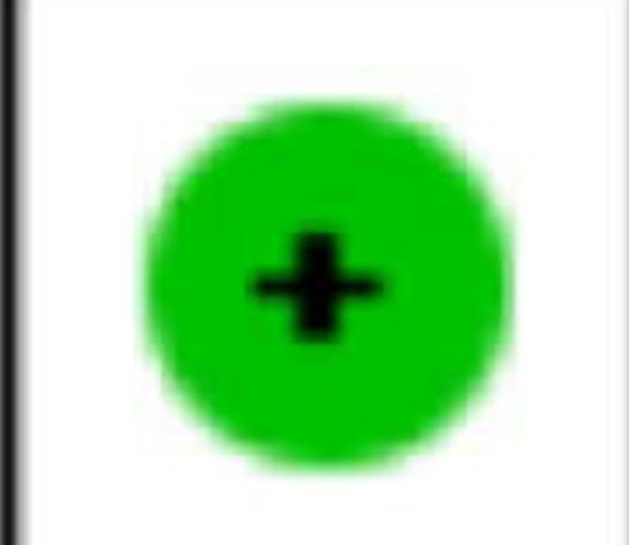 & ( & & \\
\hline & & & 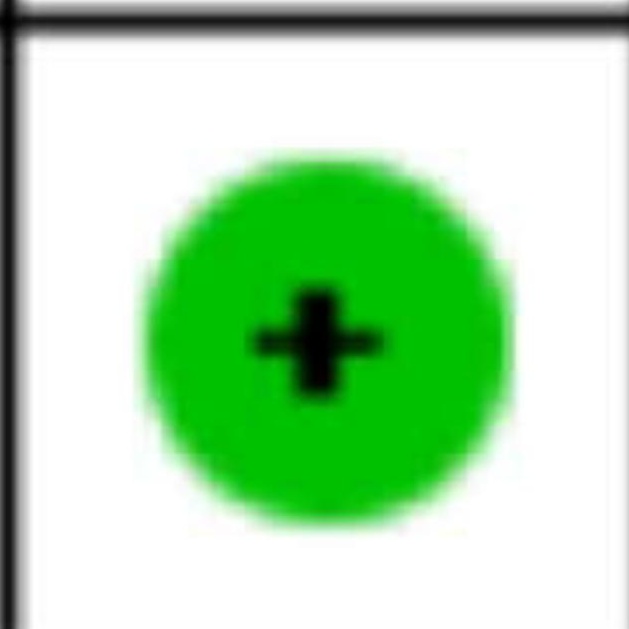 & + & & \\
\hline & ? & 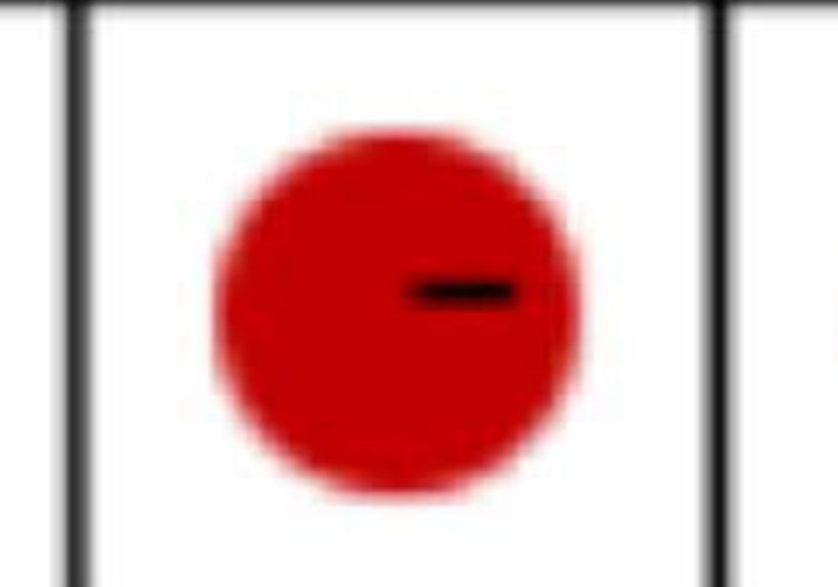 & $\bullet$ & $\odot$ & ๑ & \\
\hline & $?$ & 1 & $\bullet$ & 0 & ) & \\
\hline & + & $\bullet$ & $\odot$ & $?$ & ? & \\
\hline & † & 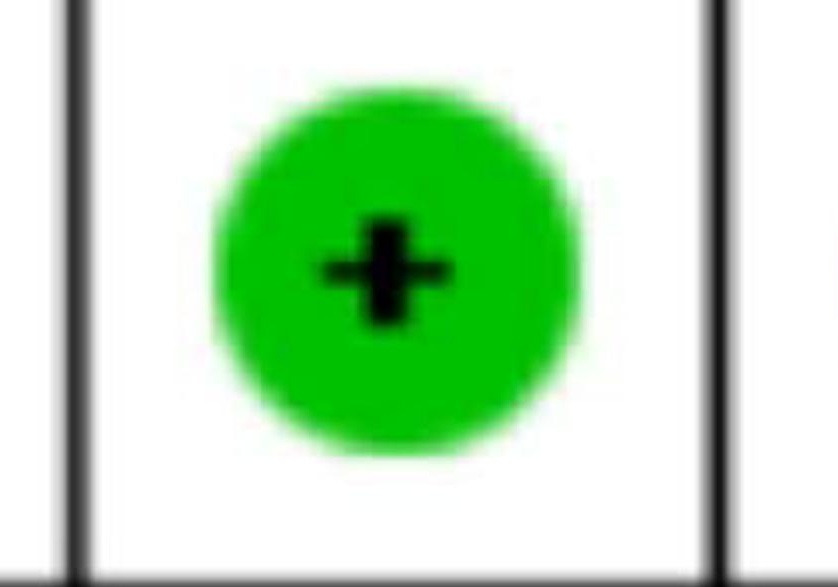 & $\bullet$ & $\odot$ & & \\
\hline & $?$ & 4 & $\odot$ & $\odot$ & 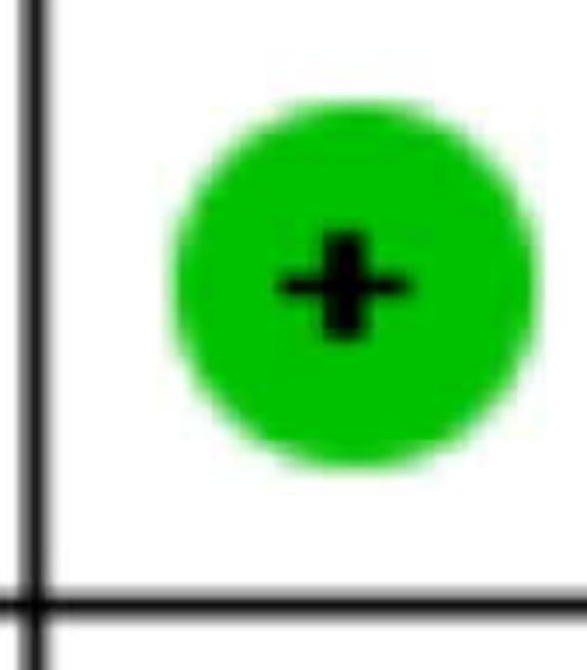 & \\
\hline & 1 & 1 & 1 & 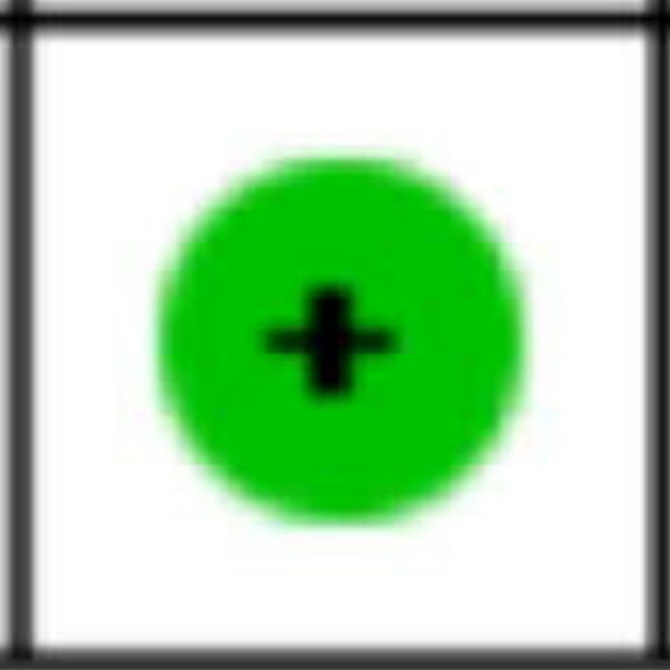 & & \\
\hline
\end{tabular}

Pradhan 2017

Pradhan 2018

Schönenberg 2005 Schönenberg 2008 
Study or Subgroup Events Total Events Total Weight M-H, Random, 95\% Cl

McGhee 2008

McGhee 2014

Mion 2017

32119

$13 \quad 28 \quad 22.7 \%$

$51 \quad 189 \quad 30.3 \%$

24100

$19 \quad 26 \quad 47.0 \%$

Total $(95 \% \mathrm{CI})$

Total events

260

83

$243100.0 \%$ 83

Heterogeneity: $\mathrm{Tau}^{2}=0.01 ; \mathrm{Chi}^{2}=2.37, \mathrm{df}=2(\mathrm{P}=0.31) ; \mathrm{I}^{2}=16 \%$

Test for overall effect: $Z=1.63(P=0.10)$
$0.58[0.35,0.95]$

$0.89[0.58,1.35]$

$0.90[0.65,1.24]$

$0.81[0.63,1.04]$

\section{M-H, Random, $95 \%$ Cl}

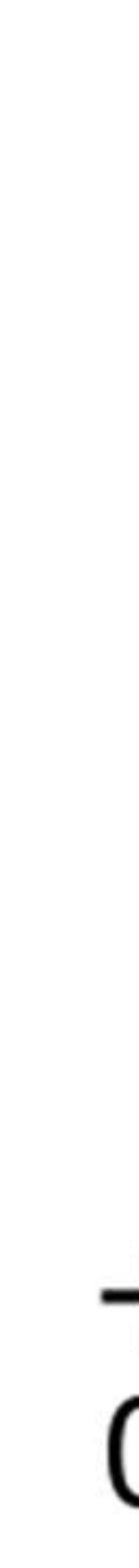

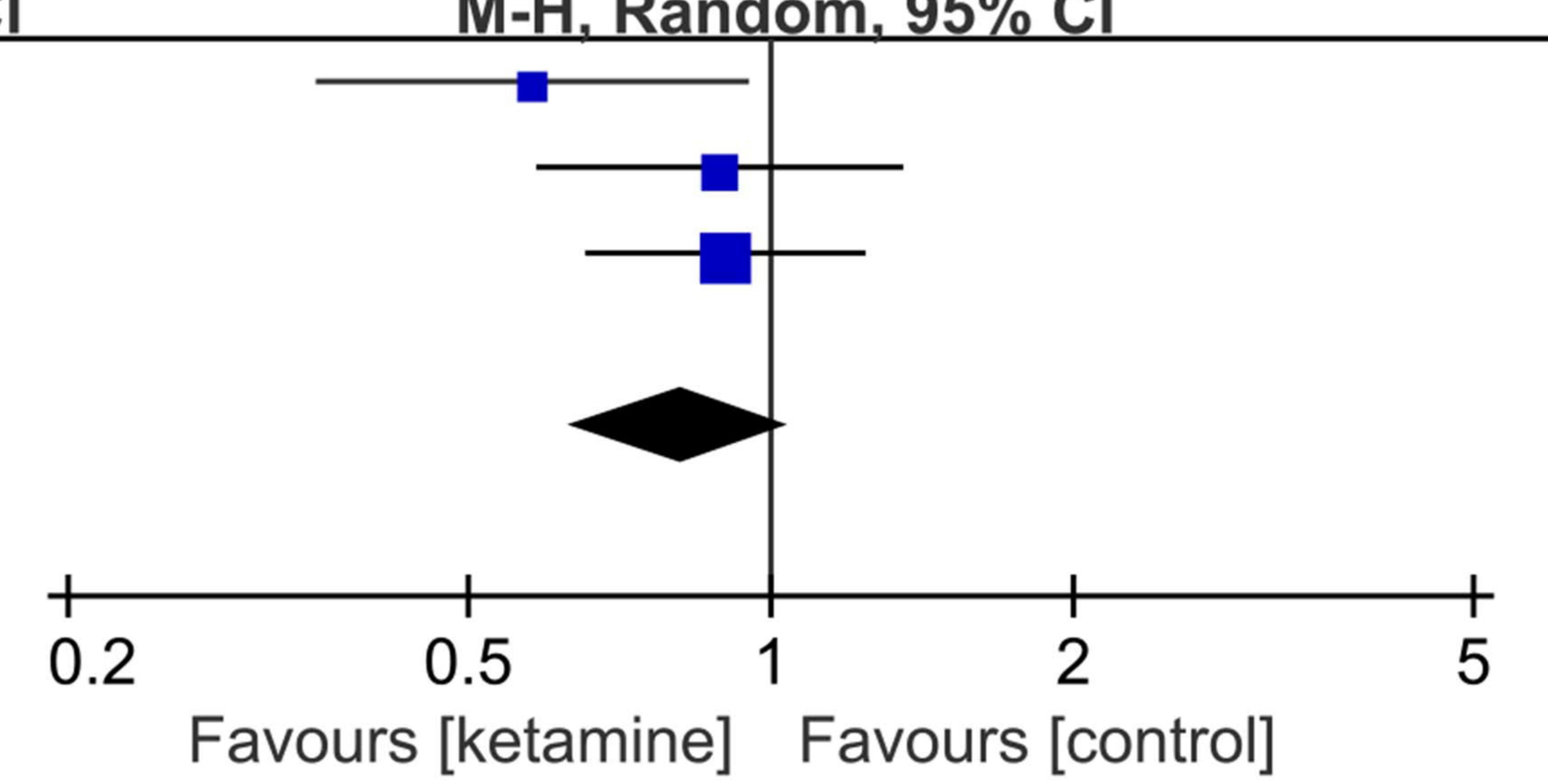


PTSD (months) - 1 day

Dadabayev 2020

Pradhan 2017

$\begin{array}{rrrrr}36.33 & 17.28 & 10 & 37 & 15.78 \\ 25.6 & 3.78 & 5 & 26.6 & 7.63 \\ 17.8 & 5.21 & 5 & 23.4 & 8.99\end{array}$

Pradhan 2017

Subtotal $(95 \% \mathrm{Cl})$

Heterogeneity: $\mathrm{Chi}^{2}=0.56, \mathrm{df}=2(\mathrm{P}=0.75) ; \mathrm{I}^{2}=0 \%$

Test for overall effect: $Z=0.85(P=0.39)$

\subsubsection{Duration of PTSD (months) - <3 days}

Schönenberg 2008

Schönenberg 2008

Schönenberg 2008

$\begin{array}{lll}9.56 & 5.23 \quad 13\end{array}$

$\begin{array}{lll}11.61 & 4.62 \quad 13\end{array}$

5.83

$7.38 \quad 2.6$

2.06

24

$14.5 \%$

$0.6 \%$

$-0.67[-15.54,14.20]$

$\begin{array}{rr}7.38 & 2.6 \\ 12.61 & 5.08\end{array}$

$\begin{array}{lll}13 & 5.2 & 1.81\end{array}$

$24 \quad 18.3 \%$

$24 \quad 50.5 \%$

$24 \quad 12.6 \%$

$96 \quad 95.9 \%$

$3.73[0.77,6.69]$ $2.83[0.19,5.47]$ $2.18[0.59,3.77]$ $3.24[0.06,6.42]$ $2.68[1.53,3.83]$

Subtotal $(95 \% \mathrm{Cl})$

52

Heterogeneity: $\mathrm{Chi}^{2}=1.00, \mathrm{df}=3(\mathrm{P}=0.80) ; \mathrm{I}^{2}=0 \%$

Test for overall effect: $Z=4.56(P<0.00001)$

\subsubsection{Duration of PTSD (months) - 1 week}
Dadabayev 2020
28.22
22.6
$\begin{array}{lll}10 & 33.67 & 20.43\end{array}$
Subtotal $(95 \% \mathrm{Cl})$
10
$\begin{array}{lll}9 & 0.3 \% & -5.45[-24.80,13.90] \\ 9 & 0.3 \% & -5.45[-24.80,13.90]\end{array}$

Heterogeneity: Not applicable

Test for overall effect: $Z=0.55(P=0.58)$

Total $(95 \% \mathrm{Cl})$

Heterogeneity: $\mathrm{Chi}^{2}=5.17, \mathrm{df}=7(\mathrm{P}=0.64) ; \mathrm{I}^{2}=0 \%$

Test for overall effect: $Z=4.26(P<0.0001)$

Test for subaroup differences: $\mathrm{Chi}^{2}=3.61 . \mathrm{df}=2(\mathrm{P}=0.16) . \mathrm{I}^{2}=44.6 \%$

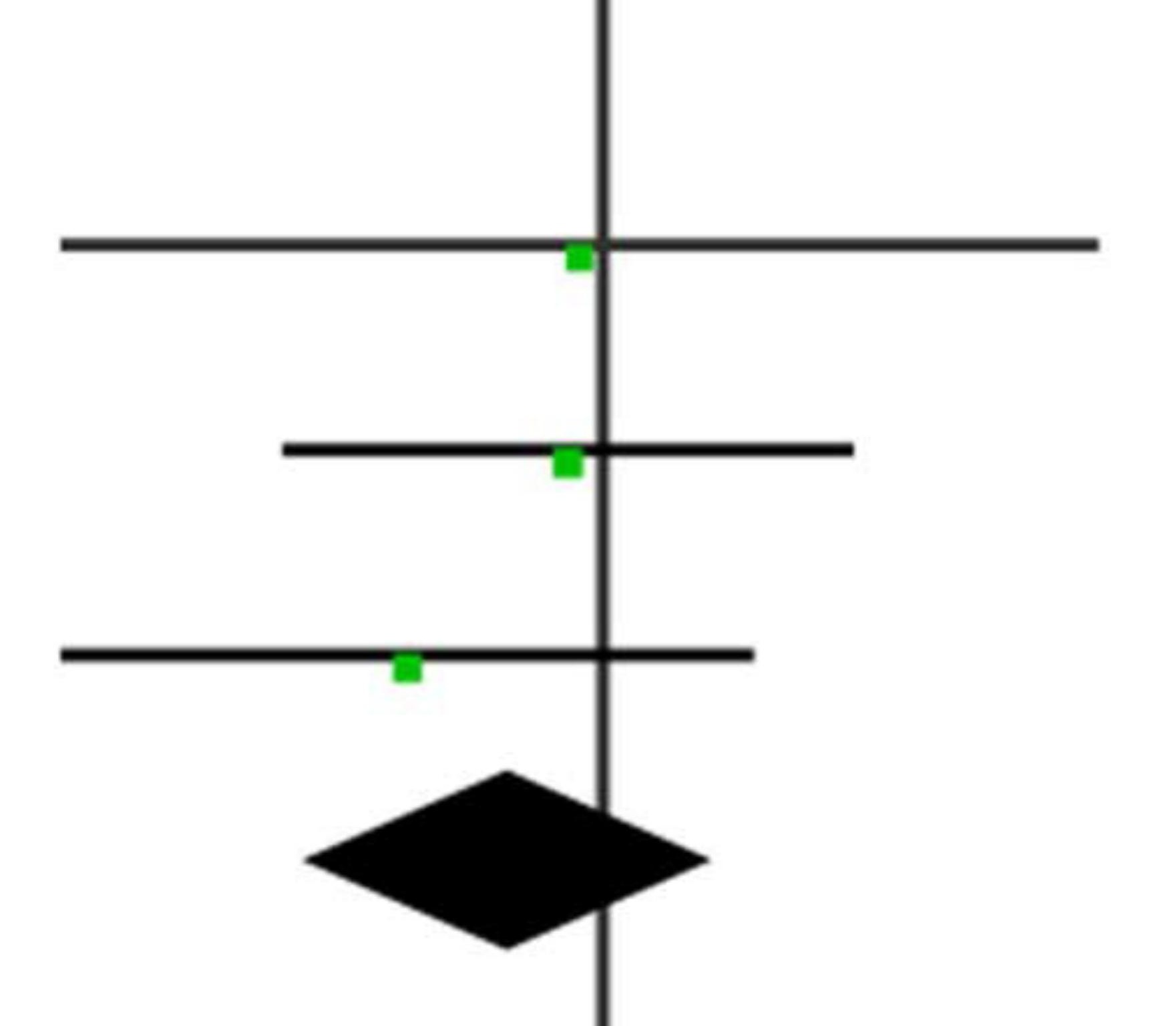


Study or Subgroup Mean SD Total Mean

SD Total Weight

IV. Random, $95 \% \mathrm{Cl}$

IV, Random, $95 \% \mathrm{CI}$

3.1.1 Duration of PTSD (years) - 1 day

Feder 2014

Feder 2021

Feder 2021

Pradhan 2018

Pradhan 2018

Subtotal $(95 \% \mathrm{Cl})$

$12.6 \quad 7.9$

$19.7 \quad 15.2$

22

$10.1 \quad 9.7$

$24.8 \quad 13.1$

$17.8 \%$

$16.5 \quad 9.6$

15

17.1

13.1

$15 \quad 8.3 \%$

$21.5 \quad 10.3$

$\begin{array}{lll}10 & 23.7 & 9.63\end{array}$

$25.8 \quad 8.15$

72

$26.3 \quad 6.82$

Heterogeneity: $\mathrm{Tau}^{2}=0.00 ; \mathrm{Chi}^{2}=2.05, \mathrm{df}=4(\mathrm{P}=0.73) ; \mathrm{I}^{2}=0 \%$

Test for overall effect: $Z=0.12(P=0.91)$

\subsubsection{Duration of PTSD (years) - 1 week}
Feder 2014
$25.76 \quad 19.4$
$\begin{array}{lll}19 & 36.32 & 13.73\end{array}$
$54 \quad 23.63$
$\begin{array}{lll}19 & 65.69 & 16.36\end{array}$
15
$7.2 \%$
$5.3 \%$
$-10.56[-21.71,0.59]$ 38
$12.5 \%-11.02[-19.61,-2.43]$
Subtotal $(95 \% \mathrm{Cl})$
30

$2.50[-2.97,7.97]$

$-5.10[-15.25,5.05]$

$-0.60[-7.40,6.20]$

$-2.20[-10.94,6.54]$

$-0.50[-7.09,6.09]$

$-0.19[-3.34,2.96]$

Heterogeneity: $\mathrm{Tau}^{2}=0.00 ; \mathrm{Chi}^{2}=0.02, \mathrm{df}=1(\mathrm{P}=0.90) ; \mathrm{I}^{2}=0 \%$

Test for overall effect: $Z=2.51(P=0.01)$

3.1.3 Duration of PTSD (years) - 2 weeks

$\begin{array}{lrrrrrrrr}\text { Feder 2021 } & 22.5 & 14.4 & 15 & 33.2 & 11.8 & 15 & 9.3 \% & -10.70[-20.12,-1.28] \\ \text { Feder 2021 } & 14.7 & 12.1 & 15 & 21.9 & 8.5 & 15 & 12.7 \% & -7.20[-14.68,0.28] \\ \text { Subtotal (95\% CI) } & & & 30 & & & 30 & \mathbf{2 2 . 0 \%} & \mathbf{- 8 . 5 5 [ - 1 4 . 4 1 , - 2 . 6 9 ]}\end{array}$

Heterogeneity: $\mathrm{Tau}^{2}=0.00 ; \mathrm{Chi}^{2}=0.33, \mathrm{df}=1(\mathrm{P}=0.57) ; \mathrm{I}^{2}=0 \%$

Test for overall effect: $Z=2.86(P=0.004)$

Total $(95 \% \mathrm{CI})$

140

$129 \quad 100.0 \%$

Heterogeneity: $\mathrm{Tau}^{2}=8.97 ; \mathrm{Chi}^{2}=12.25, \mathrm{df}=8(\mathrm{P}=0.14) ; \mathrm{I}^{2}=35 \%$

Test for overall effect: $Z=2.12(P=0.03)$

Test for subaroun differences: $\mathrm{Chi}^{2}=9.85 . \mathrm{df}=2(\mathrm{P}=0.007) . \mathrm{I}^{2}=79.7 \%$

$-3.66[-7.05,-0.27]$

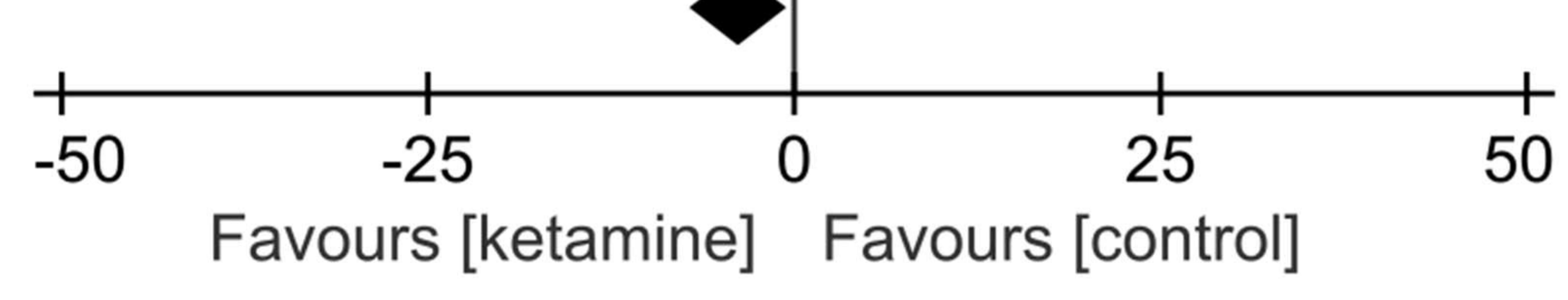


4.1.1 Duration of PTSD (months) - CAPS

$\begin{array}{lllllllll}\text { Pradhan } 2017 & 17.8 & 5.21 & 5 & 23.4 & 8.99 & 4 & 0.6 \% & -5.60[-15.52,4.32] \\ \text { Subtotal }(95 \% \mathrm{Cl}) & & & 5 & & & 4 & \mathbf{0 . 6 \%} & \mathbf{- 5 . 6 0}[-15.52,4.32]\end{array}$

Heterogeneity: Not applicable

Test for overall effect: $Z=1.11(P=0.27)$

4.1.2 Duration of PTSD (months) - IES (Reexperiencing)

$\begin{array}{lllllllll}\text { Schönenberg 2005 } & 11.19 & 4.45 & 17 & 10.75 & 4 & 27 & 8.7 \% & 0.44[-2.16,3.04] \\ \text { Subtotal }(95 \% \text { Cl) } & & & \mathbf{1 7} & & & \mathbf{2 7} & \mathbf{8 . 7 \%} & \mathbf{0 . 4 4}[-\mathbf{2 . 1 6 , 3 . 0 4 ]}\end{array}$

Heterogeneity: Not applicable

Test for overall effect: $Z=0.33(P=0.74)$

4.1.3 Duration of PTSD (months) - IES (Avoidance)

Schönenberg 2005

5.36

$17 \begin{array}{ll}13.61 & 5.352\end{array}$

$27 \quad 5.5 \%$

$-0.31[-3.56,2.94]$

Subtotal $(95 \% \mathrm{Cl})$ 17

$27 \quad 5.5 \%$

$-0.31[-3.56,2.94]$

Heterogeneity: Not applicable

Test for overall effect: $Z=0.19(P=0.85)$

4.1.4 Duration of PTSD (months) - IES (Hperarousal)

$\begin{array}{lllllllll}\text { Schönenberg 2005 } & 15.04 & 6.1847 & 17 & 13.06 & 5.5079 & 27 & 4.5 \% & 1.98[-1.62,5.58] \\ \text { Subtotal }(95 \% \text { CI) } & & & 17 & & & 27 & 4.5 \% & 1.98[-1.62,5.58]\end{array}$

Heterogeneity: Not applicable

Test for overall effect: $Z=1.08(P=0.28)$

4.1.5 Duration of PTSD (months) - IES-R

$\begin{array}{lrrrrrrrr}\text { Dadabayev 2020 } & 28.22 & 22.6 & 10 & 33.67 & 20.43 & 9 & 0.2 \% & -5.45[-24.80,13.90] \\ \text { Dadabayev 2020 } & 36.33 & 17.28 & 10 & 37 & 15.78 & 9 & 0.3 \% & -0.67[-15.54,14.20] \\ \text { Subtotal }(95 \% \mathbf{C I}) & & & 20 & & & 18 & \mathbf{0 . 4 \%} & \mathbf{- 2 . 4 4}[-14.23,9.34]\end{array}$

Heterogeneity: $\mathrm{Tau}^{2}=0.00 ; \mathrm{Chi}^{2}=0.15, \mathrm{df}=1(\mathrm{P}=0.70) ; \mathrm{I}^{2}=0 \%$

Test for overall effect: $Z=0.41(P=0.68)$

4.1.6 Duration of PTSD (months) - PCL

$\begin{array}{lrrrrrrr}\text { McGhee } 2014 & 34.57 & 15.64 & 189 & 32.98 & 15.62 & 100 & 4.1 \% \\ \text { Pradhan } 2017 & 25.6 & 3.78 & 5 & 26.6 & 7.63 & 4 & 0.9 \% \\ \text { Subtotal }(95 \% \mathrm{Cl}) & & & 194 & & & 104 & 5.0 \%\end{array}$

$1.59[-2.20,5.38]$

$-1.00[-9.18,7.18]$

$1.13[-2.30,4.57]$

Heterogeneity: $\mathrm{Tau}^{2}=0.00 ; \mathrm{Chi}^{2}=0.32, \mathrm{df}=1(\mathrm{P}=0.57) ; \mathrm{I}^{2}=0 \%$

Test for overall effect: $Z=0.65(P=0.52)$

4.1.7 Duration of PTSD (months) - ASDS (Dissociation)

$\begin{array}{lllllllrr}\text { Schönenberg 2005 } & 10.91 & 4.16 & 17 & 8.51 & 3.89 & 27 & 9.7 \% & 2.40[-0.06,4.86] \\ \text { Schönenberg 2008 } & 12.61 & 5.08 & 13 & 9.37 & 3.92 & 24 & 5.8 \% & 3.24[0.06,6.42] \\ \text { Subtotal (95\% CI) } & & & \mathbf{3 0} & & & \mathbf{5 1} & \mathbf{1 5 . 5 \%} & \mathbf{2 . 7 2}[\mathbf{0 . 7 7}, \mathbf{4 . 6 6}]\end{array}$

Heterogeneity: $\mathrm{Tau}^{2}=0.00 ; \mathrm{Chi}^{2}=0.17, \mathrm{df}=1(\mathrm{P}=0.68) ; \mathrm{I}^{2}=0 \%$

Test for overall effect: $Z=2.73(P=0.006)$

4.1.8 Duration of PTSD (months) - ASDS (Reexperiencing)

$\begin{array}{llllllll}\text { Schönenberg 2005 } & 9.44 & 5.24 & 17 & 7.97 & 4.11 & 27 & 6.8 \% \\ \text { Schönenberg 2008 } & 9.56 & 5.23 & 13 & 5.83 & 2.06 & 24 & 6.7 \% \\ \text { Subtotal (95\% CI) } & & & \mathbf{3 0} & & & \mathbf{5 1} & \mathbf{1 3 . 5 \%}\end{array}$

$1.47[-1.46,4.40]$

$3.73[0.77,6.69]$

$2.59[0.38,4.81]$

Heterogeneity: $\mathrm{Tau}^{2}=0.29 ; \mathrm{Chi}^{2}=1.13, \mathrm{df}=1(\mathrm{P}=0.29) ; \mathrm{I}^{2}=11 \%$

Test for overall effect: $Z=2.29(P=0.02)$

4.1.9 Duration of PTSD (months) - ASDS (Avoidance)

$\begin{array}{lrrrrrrrr}\text { Schönenberg 2005 } & 6.98 & 3.46 & 17 & 7.27 & 4.68 & 27 & 10.1 \% & -0.29[-2.70,2.12] \\ \text { Schönenberg 2008 } & 7.38 & 2.6 & 13 & 5.2 & 1.81 & 24 & 23.2 \% & 2.18[0.59,3.77] \\ \text { Subtotal (95\% CI) } & & & \mathbf{3 0} & & & \mathbf{5 1} & \mathbf{3 3 . 3 \%} & \mathbf{1 . 1 2 [ - 1 . 2 8 , 3 . 5 2 ]}\end{array}$

Heterogeneity: $\mathrm{Tau}^{2}=1.96 ; \mathrm{Chi}^{2}=2.81, \mathrm{df}=1(\mathrm{P}=0.09) ; \mathrm{I}^{2}=64 \%$

Test for overall effect: $Z=0.92(P=0.36)$

\subsubsection{Duration of PTSD (months) - ASDS (Hperarousal)}

$\begin{array}{lrlllllll}\text { Schönenberg 2005 } & 14.67 & 5.69 & 17 & 12.31 & 5.98 & 27 & 4.7 \% & 2.36[-1.16,5.88] \\ \text { Schönenberg 2008 } & 11.61 & 4.62 & 13 & 8.78 & 2.01 & 24 & 8.4 \% & 2.83[0.19,5.47] \\ \text { Subtotal (95\% CI) } & & & 30 & & & \mathbf{5 1} & \mathbf{1 3 . 1 \%} & \mathbf{2} .66[0.55, \mathbf{4} .77]\end{array}$

Heterogeneity: $\mathrm{Tau}^{2}=0.00 ; \mathrm{Chi}^{2}=0.04, \mathrm{df}=1(\mathrm{P}=0.83) ; \mathrm{I}^{2}=0 \%$

Test for overall effect: $Z=2.47(P=0.01)$

Total $(95 \% \mathrm{Cl})$

390

$411 \quad 100.0 \%$

Heterogeneity: $\mathrm{Tau}^{2}=0.00 ; \mathrm{Chi}^{2}=12.36, \mathrm{df}=15(\mathrm{P}=0.65) ; \mathrm{I}^{2}=0 \%$

Test for overall effect: $Z=4.40(P<0.0001)$

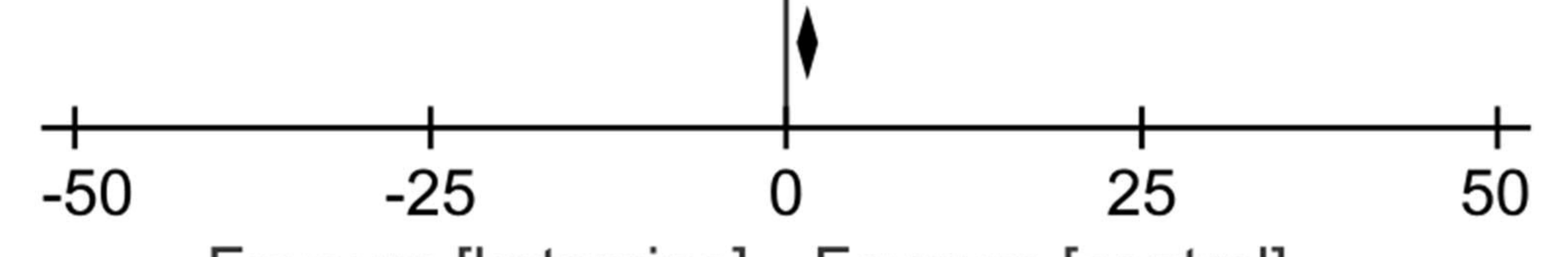

